KEYWORDS

Economic growth

Economic gap

Geography

Economic history

Political aspects

Social aspects

Social mobility

Economic analysis

Mathematical models

Latin America

José Antonio Alonso

Professor of Applied Economics

Director, Instituto Complutense de

Estudios Internacionales (ICEI)

Madrid

$\infty$ j.alonso@ccee.ucm.es
CEPAL REVIEW 93 - DECEMBER 2007

\section{Inequality, institutions and progress: a debate between history and the present}

\author{
José Antonio Alonso
}

$\mathrm{T}$

his article analyses current attempts to interpret the factors underlying long-term economic growth, paying special attention to the Latin American case. It discusses both the interpretations whose advocates claim that geographic conditions have a decisive role in shaping the development process and those according to which colonization is seen as giving rise to an institutional framework ill-suited for development. The author -based on his own estimates- emphasizes the importance of market access and the effect of social fragmentation on the establishment of an efficient and credible institutional framework. The article concludes with a discussion of the impact of inequality on both the quality of institutions and the dynamics of growth. 
I

\section{Introduction}

Economic theory offers a relatively convincing view of the immediate factors that promote modern economic growth: the accumulation of physical and human capital and technological progress are said to be its main explanatory factors. However, these factors by themselves can hardly account for the extraordinary inequalities observed at the international level or explain the historical process of divergence underlying them (Pritchett, 1997). The stubborn persistence of underdevelopment defies a simple economic interpretation and highlights the need for a subsequent analysis in order to identify the forces that determine long-term economic growth. The purpose of such an exercise would be to explain what caused the immediate variables mentioned above to evolve so unevenly in different countries and regions. This compels us to analyse more fundamental factors and longer time spans in order to account for economic progress or, in other words, to look to the ultimate causes of long-term growth.
In the last few years, various contributions have been made in this regard, with economists, political scientists, naturalists and historians all weighing in on the subject. Their efforts go beyond mere historical inquiry, since they seek to identify the key factors that explain economic progress in the hope of finding an effective solution for underdevelopment. It is a debate between history and the present. Unfortunately, the urge to find a single, fundamental cause of development has led to many synthetic explanations and to overly broad interpretations of the secular trend which do not always account for the complexity of the dynamics of economic and social change which development entails. The purpose of this article is not to correct this lack, since such a task would lie far beyond this author's capacities. This article simply aims to highlight some of the limitations of the dominant interpretations and to mention some additional factors that should be borne in mind when seeking to explain the development process.

\section{II}

\section{Institutions and geography}

The recent literature offers two main hypotheses regarding the ultimate causes of development. The first stresses the decisive importance of geographic factors; it assumes that the soil, climate, environment and physical accessibility of a region determine the chances of progress (Gallup, Sachs and Mellinger, 1998; Sachs, 2001, or Diamond, 1998). Three variations of this tra c dition focus on different, though not incompatible, types of geographic influence: (i) climate, which conditions attitudes regarding effort and has an effect on people's productivity; (ii) geography, which determines technological options, land productivity and conditions in terms of mobility and transportation; and (iii) the persistence of certain diseases influenced by the bio-physical conditions of the environment.

According to all of these theories, the factors that determine the possibilities of development are beyond human control, or at least relatively so. There are various sorts of evidence that support this theory; the most cogent ones, however, refer to the difficulties that tropical or landlocked countries without navigable rivers have been implementing a successful development strategy. The costs of certain epidemic diseases and their prevalence in specific areas - which happen to be in the tropics - lend added weight to this approach by underscoring the difficulties that certain environmental conditions pose for life in general and for production activities in particular.

Notwithstanding the recognized importance of geographic aspects, the proponents of this thesis do not seem to have proven that the natural environment is the ultimate cause of economic backwardness. The relatively unchanging nature of geographic conditions makes them unlikely to explain the sudden economic shifts experienced by many countries at specific points in time (present-day China comes to mind). Nor can 
it explain the contrasting economic performance of neighbouring countries that share a similar geographic environment (Mexico and the United States, for example, or the Democratic People's Republic of Korea and the Republic of Korea).

The strongest argument against this approach, however, lies in the regression suffered by certain societies that used to play a distinguished role in their region but which now lag behind their neighbours. This is the "reversal of fortune" to which the specialized literature refers. The clearest examples of this phenomenon are the Inca, Aztec or Mogol civilizations, which were noted for their complexity and wealth circa 1500, and are now part of the developing world. Acemoglu, Johnson and Robinson (2002) have attempted to show that these reversals of fortune are more than a string of isolated cases. Using urbanization as an indicator of prosperity for a sample group of developing countries, they have found a negative correlation between the percentage of the population living in urban areas five centuries ago and current gross domestic product (GDP). This finding evidences the differences existing between shifts in the relative position of these countries and their more permanent geographic conditions. However, the questionable quality of the data employed and the ratio's high levels of dispersion cast doubt on the value of this exercise.

It should be noted that these critiques, although well founded, do not mean that environmental conditions cannot influence development processes. First of all, geographic conditions may not be as static as they appear; changing natural or environmental conditions may have contributed to the reversals mentioned above. Changes in climate caused by severe droughts or the degradation of fragile ecosystems, along with escalating clashes between groups over the control of resources, appear to have been behind the collapse of relatively advanced societies such as those of the Huari, Tiahuanaco, Calakmul or Cahokia peoples (Diamond, 2005, or Mann, 2006). Furthermore, it is possible that certain environmental characteristics may be of little significance in some contexts but may matter a great deal in others. For example, the location of certain Latin American capitals in the interior may have had little relevance at the time of their founding, when exchanges were few and defensive considerations were given top priority, but it may have become a hindrance to communication and transportation once their economies joined the world market. In this regard, the orientation of Latin America along a primarily vertical axis, the presence of mountain ranges which fragment the region and the absence of significant navigable rivers must have been a major obstacle to the movement of people, crops, ideas and goods. ${ }^{1}$ Of course, the fact that geographic factors are important does not necessarily mean they are the cause of economic backwardness.

Hence the idea that institutions (not geography) determine development. By "institutions", we mean a system of incentives (and penalties) that stem from society and that structure the interaction between agents, thus conditioning collective behaviour. Institutions help set expectations regarding the behaviour of the group, reducing society's uncertainties and transaction costs. In generic terms, institutions help to establish incentives for investment in physical and human capital and thus determine the chances of aggregate growth (North, 1993).

The proponents of this idea suggest that the institutional framework of developing countries was determined by the type of colonization they experienced. The settlement and farming patterns adopted by colonists in conquered lands shaped the institutions they created. Thus, underdevelopment is not a result of factors which, like geography, are beyond human control, but rather of phenomena - such as institutions - which are genuine social creations, albeit ones which date back to the country's forced insertion into the global economy.

Variations can also be found within this tradition. On the one hand, Acemoglu and Johnson (2003) or Acemoglu, Johnson and Robinson (2001, 2002 and 2006) argue that colonial settlement patterns can explain the type of institutions - private-property-based or extractive - that were established in conquered lands. In areas where the unhealthy conditions of the environment prevented Europeans from establishing settlements, where there were large populations that could be directly exploited, forced into servitude or otherwise coerced, or where little extractable wealth existed, Europeans made little effort to develop systems for increasing aggregate welfare by establishing primarily extractive institutions. In contrast, in places where colonization was based on the occupation of virgin lands and the exploitation of their resources, the colonists themselves tried to develop institutions - partly imported from their native countries - which protected private property, encouraged free markets and spurred growth. While environmental conditions - particularly endemic diseases - may also have influenced development, they did not do so directly, but rather through the colonization model they fostered. In areas with a high rate

\footnotetext{
${ }^{1}$ For a weighted analysis of the impact of various geographic factors on Latin American development, see Gallup, Gaviria and Lora (2003).
} 
of deadly disease, Europeans avoided building settlements, choosing instead to establish extractive institutions that ultimately hindered development.

This same hypothesis has been used to explain reversals of fortune. The most populated and developed areas - that is, the wealthiest ones at the time of colonization - saw the establishment of extractive institutions that would later hamper their development. Conversely, in the least populated areas (originally the poorest ones), a settlement pattern predominated that would eventually lead to the creation of the type of market institutions that would ultimately drive their development. Thus, the reversal of fortune is actually a "reversal of institutions".

Another variation on this approach has been suggested by Engerman and Sokoloff (1997, 2002, 2005 and 2006), who argue that initial factor endowments not only determine the distribution of income, but also give shape to institutions that match those patterns (Engerman, Haber and Sokoloff, 2000; Sokoloff and Engerman, 2000). Income distribution patterns were highly unequal in areas suited for large-scale agriculture which enjoyed substantial economies of scale and had access to slave labour (Brazil or the Caribbean, for example), or in places where large indigenous populations could be exploited and forced into labour (Mexico or the Andean region). These environments generated exclusionary institutions that served a small elite and that had a limited capacity to generate effective results. Conversely, places with a small indigenous population and an environment better suited to family agriculture (certain parts of the east coast of the United States, for example) generated more democratic institutions which focused on providing public goods, protecting property rights and encouraging economic opportunities. Thus, initial factor endowments influence the level of social inequality and the resulting institutions; the institutions, in turn, affect the chances of growth.

Consequently, whether because of the nature of settlement patterns or as a result of initial factor endowments, institutions determine the development path. Institutions are shaped by distribution patterns and vice-versa. To the extent that Latin America is a reference point for these studies (particularly those of Engerman and Sokoloff), the hypothesis they suggest is a good starting point for the analysis of the region's development agenda. Before reaching any conclusions, however, their arguments must be examined.

\section{III}

\section{History without "historic data"}

The institutional explanation of development has found considerable support within academic circles and international organizations. Among the latter, it has become the dominant interpretation of the relationship among poverty, institutions and development, creating what appears to be a "new orthodoxy" on the subject (Dobado, 2007). Echoes of this view can be found in two World Bank studies on the relationship between inequality and development in Latin America: "Inequality in Latin America: Breaking with History?" (De Ferranti, Perry and others, 2004) and "Poverty Reduction and Growth: Virtuous and Vicious Circles" (Perry, Arias and others, 2006). It is also the basic premise of the "World Development Report 2006: Equity and Development" (World Bank, 2005).

There are several possible explanations for the strong support received by the institutional hypothesis. First of all, it is consistent with the basic principles of liberal Anglo-Saxon philosophy - Locke, Smith or Stuart Mill - that informs a great part of economic doctrine and highlights the role that the liberal order and property rights play in laying the foundations of progress. Second, it relies neither on geographic determinism - which focuses on factors that are beyond human control (as Diamond, 2005, might suggest) - nor on Weberian culturalist approaches, which draw a distinction between good colonists and bad colonists (see Landes, 1998). Contrary to both positions, the institutional approach attributes underdevelopment to the social framework that shapes human conduct (in other words, to institutions) in an attempt to explain the phenomenon in endogenous terms. This effort to internalize institutions by means of these rather clever procedures is one of the unquestionable merits of these proposals. Finally, this vision is consistent with the messages that international organizations are attempting 
to promote regarding the role of institutional quality and social cohesion in national development strategies.

Are these hypotheses solidly supported by historical evidence? Not entirely. The historical data they cite do not fully support their claims. The evidence provided by Acemoglu, Johnson and Robinson (hereinafter referred to as AJR) and Engerman and Sokoloff (hereinafter referred to as ES) consists of so-called "natural experiments" arising from various colonization experiences. According to Engerman and Sokoloff (2006, p. 38), "the history of European colonization provides scholars with a rich supply of evidence, a research laboratory, that can be used to study economic performance and the evolution of institutions over the long run." The available data, however, do not justify the generalizations they sometimes make, and their information is, at times, debatable.

The critics may base their arguments on the works of the economic historians themselves (particularly Latin Americanists), whose analyses and evidence that have little in common with the conclusions reached by AJR and ES. The following subsections cover the four main objections which can be raised in this regard.

\section{Too many generalizations}

First of all, the approaches of ES and AJR entail too many generalizations. This criticism can be divided into two complementary arguments: on the one hand, a single factor can hardly explain the many different situations in which developing countries currently find themselves; on the other, even the historical factors mentioned by these authors to illustrate their hypotheses are not applicable to all the countries considered.

With regard to the first point, the relevant question would be whether the disparate development paths followed by different countries can be explained by a vague and general description of colonization patterns. Is the dichotomy between extractive institutions and private property enough to explain the diversity of situations found in the developing world? Latin America is a good example, since few colonial systems generated an institutional framework as unified and homogeneous as the Spanish one (Elliott, 2006). How could a common institutional framework produce such diverse results in terms of development? As Coatsworth (2007) points out, in 1800 the differences in productivity between the richest and poorest Latin American colonies were almost as great as the differences between the richest and poorest regions of the world as a whole.

As for the second point, it is highly unlikely that the guidelines used to identify colonization models can be applied across the board to every country studied. For example, it is doubtful whether an extractive colonization model can be attributed to all of Latin America, or that a market-based system can be attributed to all of the eastern United States (as AJR argues). In the first case, there are exceptions, at least in the Southern Cone of Latin America; in the second, there are also exceptions, in the states of Virginia and the Carolinas. Why didn't this discrepancy result in clearly differentiated development paths? Moreover, the Southern Cone colonization model, which is more similar to that of the east coast of the United States, should have given rise (according to ES) to democratic, inclusive institutions; inequality levels in Chile, however, are among the highest in the region, and those of Argentina and Uruguay, although lower, are equally high in global terms.

Even the countries that had quite similar patterns of colonial exploitation followed very different development paths, contrary to what AJR and ES suggest. This was the case, for example, of Cuba and Brazil, where a similar colonization model of plantations and slave labour was applied. Nevertheless, while one of these countries - Cuba - became one of the richest societies in Latin America in the early nineteenth century, the other one - Brazil - became one of the poorest. Another clear example is that of Central America, where countries such as Guatemala or Nicaragua have low income levels and high degrees of inequality and yet were not colonized under the plantation-slave or forced-mining models typical of extractive institutions.

\section{Lack of historical data}

Another characteristic of the institutionalist interpretation is its use of history to explain the ultimate causes of underdevelopment. Its references to history are broad and lacking in details about actual "historical facts"; in their interpretations, AJR and ES include very few historical data, sequence analyses or detailed contextual studies. Instead, they offer broad interpretations of "metahistorical narratives" (Coatsworth, 2007, p. 2) that are constructed on a very limited empirical basis which, in the best of cases, suggests rather than demonstrates the hypotheses they are trying to defend. As noted by Dobado (2007), the economic history of Latin America or other former colonies is rarely mentioned in the writings of EngermanSokoloff or in those of Acemoglu-Johnson-Robinson. A quick glance at the bibliographies of their works is enough to corroborate this fact.

This lack of historical data would matter less if the analyses offered by AJR and ES were supported by 
evidence and findings from historical studies of the region. But that does not always seem to be the case. Firstly, as noted earlier, they seem to have made very little use of the research carried out by specialists in economic history, and they have not compensated for that shortcoming by providing their own reconstruction of history. But they also take for granted the existence of a reality which, in many cases, has been challenged by historical studies. This issue will be taken up later in this article; for now, suffice it to say that AJR speaks of the existence of a large indigenous population as a factor leading to the establishment of an extractive colonization model in Mexico or in the Andean region. Can this argument be maintained without modifications, when we know full well that $90 \%$ of the local population disappeared within just one century? Did not the demographic catastrophe that followed the arrival of the first Europeans have some impact on the type of institutions that arose during the colonial period? (Dobado, 2007).

\section{Excessive confidence in historical inertia}

One of the positive contributions of the institutional approach is that it has brought back the temporal sequence, or historic inertia. As noted by Banerjee and Iyer (2002, p. 2), "in the new institutionalist view, history matters because history shapes institutions and institutions shape the economy."

Indeed, many of the obstacles to development are hard to understand without referring back to the historical processes from which they originated. It would be going too far, however, to say that the explanation for backwardness necessarily lies in the colonial era. Przeworski and Curvale (2005, p. 2) are right when they argue that "institutionalism is a mirror image of the dependency theory"; though in this case the institutions, shaped in their time by the colonial powers, are acting as determinants of development.

In regions such as Latin America, this means looking 500 years in the past to explain the shortcomings of the present. Has nothing important happened since then? That would be surprising, given that, in the interim, many historically significant events have occurred in the region, including (i) independence, which represented a crucial break in the patterns of international insertion, the structure and dynamics of society and the make-up of institutions in these countries; (ii) the transportation revolution of the mid-nineteenth century, which reduced potential agglomeration economies at a time when Latin America had not yet begun to industrialize; (iii) the rise in prices of raw materials during the intercentury period, which accentuated the primary-export specialization of the region; (iv) the State-led industrialization policies of the second half of the twentieth century, which helped enhance manufacturing capabilities, but also led to significant imbalances in the management of national economies; and finally, (v) the debt crisis and the economic reforms of the 1980s, which influenced changes in the orientation of economic policy. These are all important events in the economic history of the region, but they are not even considered by the proponents of the institutional thesis.

\section{Questionable interpretation}

Disregard for historical research and a penchant for generalizations lead AJR and ES to interpretations of historical data that are not borne out by the findings of specialized studies. While there is no space here for an exhaustive list of their inconsistencies, some representative examples are listed below:

(i) It is not clear that the backwardness of Latin America originated during the time period mentioned by AJR and ES. Coatsworth (2005, p. 8) dates it much later, around the time of independence. He points out that Latin America was not underdeveloped by any conventional standard (such as per capita GDP) until some time between 1750 and 1850 . Haber (1997) also traces the backwardness of the region to that period (nineteenth century), as does Bulmer-Thomas (1994). Prados de la Escosura (2005) compares the region not with the United States but with the rest of the members of the Organisation for Economic Co-operation and Development (OECD), and moves the date forward by almost a century: "Latin America's retardation, vis-à-vis OECD countries, appears to be a late twentieth century phenomenon."

(ii) Their emphasis on the encomienda as an example of an extractive institution established in Latin America appears to contradict the proven decline of that institution from the seventeenth century onward (Carmagnani, 2004). And neither can the hacienda model be generalized as the predominant form of agrarian exploitation in Latin America (Miño, 1991).

(iii) Contrary to the assertions of ES, forced labour in the mines does not appear to have been a standard recruitment procedure, except maybe during the early stages of colonization (Velasco, Flores and others, 1989). In fact, data on Mexico suggest that 
miners' wages were relatively high, thus refuting the idea that working conditions and wages were little short of slavery (Dobado, 2007).

(iv) The Spanish colonizers do not appear to have neglected the regulation of property rights, and there is no evidence of legal restrictions that would have prevented the indigenous population from owning land or mines (Dobado, 2007).

(v) The picture that Engerman and Sokoloff paint of a highly polarized colonial society, while accurate to some extent, does not take into account the existence of a middle - and mestizo - class that in some cases was quite substantial (Carmagnani, 2004). The available data seem to suggest that the comparatively high levels of inequality in Latin America are more a product of the post-nineteenth-century period than the immediate consequence of colonization (Coatsworth, 2005; Williamson, 1999).

(vi) Finally, a comparative study of the evolution of institutional frameworks in Spain and Latin America suggests that there are similarities that cannot be attributed either to factor endowments or to incomedistribution patterns, thus refuting the arguments of ES (Coatsworth and Tortella, 2002).

Of the points mentioned above, it seems particularly relevant that there is no evidence of anomalous inequality levels in Latin America in the period immediately after colonization, since this is one of the basic assumptions put forward by ES (who do not, in fact, provide any evidence for it). The data seem to suggest that, although inequality in Hispanic America was high, it did not exceed that of other regions which did have a successful industrialization experience (Coatsworth, 2005). For example, according to Gourguignon and Morrison (2002), in 1820 the level of inequality in Mexico was similar to that of the United Kingdom; Williamson (1999), using a wage-rent ratio of land, confirms that the sharpest increase in inequality occurred during the decades preceding the First World War; Gelman (2007) suggests that, to a large extent, the current inequality in Argentina can be traced to the last third of the nineteenth century; and that finding seems to apply to Uruguay as well, according to the studies of Bértola Flores (2005).

As it happens, these studies refer not only to income distribution, but also to the most important asset of the time: land. Coatsworth (2005, p. 139), for example, points out that land ownership (and wealth in general) was no more concentrated in Latin America than it was in the thirteen British colonies (or in industrialized Great Britain itself). This underpins his conclusion that "the thesis put forward by Engerman and Sokoloff, while plausible, is almost certainly mistaken".

\section{IV}

\section{Which institutions?}

If the proponents of the institutional hypothesis invoke history without studying it, the objection could also be raised that they stress the importance of institutions without offering a clear definition of what is understood by "institution", or what steps could be taken to create the institutional framework needed to foster development. This is no small matter, given the intense debate that surrounds the issue.

Indeed, neither AJR nor ES make any effort to analyse or explain the concept of institutions used in their arguments. The references AJR make to the two types of institutions - extractive and market-oriented - on which their hypothesis is based are generic and vague. What features should institutions have in order to be defined as extractive or market-oriented? No clear answer is provided to that question.

Despite their silence on the subject, it is possible to infer some of the questionable doctrinal assumptions that underpin - sometimes implicitly - the positions of AJR and ES. Specifically, their main assumptions are as follows: (i) institutions are the formal framework that establishes the set of restrictions within which agents operate; (ii) it is possible to establish, a priori, a universally valid optimal (or at least adequate) framework of institutions that will promote development (the so-called "market institutions" which the authors never define) and (iii) this framework consists mainly of institutions devoted to protecting property rights and guaranteeing 
democratic forms of government (as well as institutions that provide public goods - particularly the training of human resources).

This is clearly a limited understanding of what constitutes an institutional framework. AJR and ES fail to consider two particular issues that are essential when interpreting the development process: the importance of informal institutions and the predominantly contingent nature of the institutional framework. These may be summarized as follows.

\section{Formal and informal institutions}

The first problem is the failure of AJR and ES to consider the role of informal institutions - that is, institutions that cannot be specifically defined, and are based less on laws or rules than on beliefs, traditions and cultures - in economic and social life. There are two different types of institutions: formal ones that are open to public scrutiny and provide a framework of incentives (and penalties) that are recognizable by society, and informal ones that are more difficult to identify, partly because the incentives (and penalties) they offer are less explicit, and partly because they sometimes represent highly specific responses to the circumstances of a given social group (not of society as a whole). While formal institutions are based on impersonal relations and usually create universal (or multilateral) frameworks of agreement, informal institutions tend to be more interpersonal, tacit and custom-based. As societies modernize and the market becomes a more dominant force, informal institutions tend to give way to institutions of an explicit, formal nature. Thus, for example, traditional forms of land ownership, deeply rooted in the local memory, give way to official property registry systems, and communal forms of labour based on agreement or custom are replaced by explicit labour contracts. Informal institutions figure more prominently in traditional economies and societies that are more fractionalized.

Indeed, in a fairly non-mercantile economy (for example, in poorer countries, or in the agricultural sectors of such countries), informal institutions may be relatively efficient, since they are based on custom and on familiarity and trust between agents. They reduce transaction costs considerably although they do so at the expense of market expansion and productive specialization. As the circle of relations among agents expands, the potential for opportunistic behaviour increases. Consequently, transaction costs rise, and formal, multilateral rules of an impersonal nature become necessary (Bardhan, 2005). This process was studied by
Greif (1994 and 2004) in connection with contractual guarantees for long-distance trade between Genoa and North Africa during the fifteenth and sixteenth centuries (Greif, Milgrom and Weingast, 1994).

The importance of institutions lies not only in their ability to reduce transaction costs, but also in their ability to foster social change and adapt to the new needs of a changing world. In this regard, formal institutions offer more advantages than informal ones. While formal institutions are more transparent and open to criticism, informal institutions are more opaque and bound by inertia; being narrow in scope, they also hinder social mobility. North (2005, p. 157) points out that, whereas formal institutions can be changed by a decision, informal institutions are not easily influenced by a deliberate short-term change, and their enforcement features are only imperfectly subject to deliberate control.

In short, the increasing mercantilization of societies - their development process - appears to go hand-inhand with the gradual disappearance of informal (and communal) institutions, and their replacement by more formal (and universal) mechanisms. This process creates more opportunities for social change, improving the "adaptive efficiency" of institutions. As North (2005) points out, obtaining an efficient institutional response at a given moment is not as important as ensuring that the institutional framework will be able to adapt to changing economic circumstances. From this standpoint, the gradual formalization of the institutional framework is not only a product of development, but also a factor that can help encourage it. Conversely, the prevalence of informal institutions may be an obstacle to change. Informal institutions may, in fact, be used by certain groups as a mechanism for resisting a system they perceive as foreign. This explains why informality is predominant in highly fractionalized societies. Latin America is one example of this phenomenon (Perry, Maloney and others, 2007).

The effectiveness of formal institutions may be undermined by the continued presence, underground, of informal institutions with high enforcement capacities. As is well known, institutions exist if they are able to shape social behaviour, generating predictable behaviour in individuals (North, 1990). In order to generate regular behaviour, however, an institution must be conceived as a system that encourages individuals to identify with the behaviours that are expected in light of the framework of incentives established by the system, thus giving rise to an endogenous or self-sustaining structure. In other words, a norm that is not followed (and that no one expects others to follow) does not constitute an 
institution, regardless of whether it is embodied in a law or an organization. Consequently, it is just as important to analyse existing rules as it is to study the reasons individuals have for following them. It may be that, when an attempt is made to superimpose a formal institutional structure on a previously existing (informal) one, the resulting structure will be inefficient, as it will be unable to effectively mould social behaviour. This explains the limited success of "institutional transplant" formulas intended to replicate in a developing country

FIGURE 1

Linguistic and ethnic fractionalization and level of development
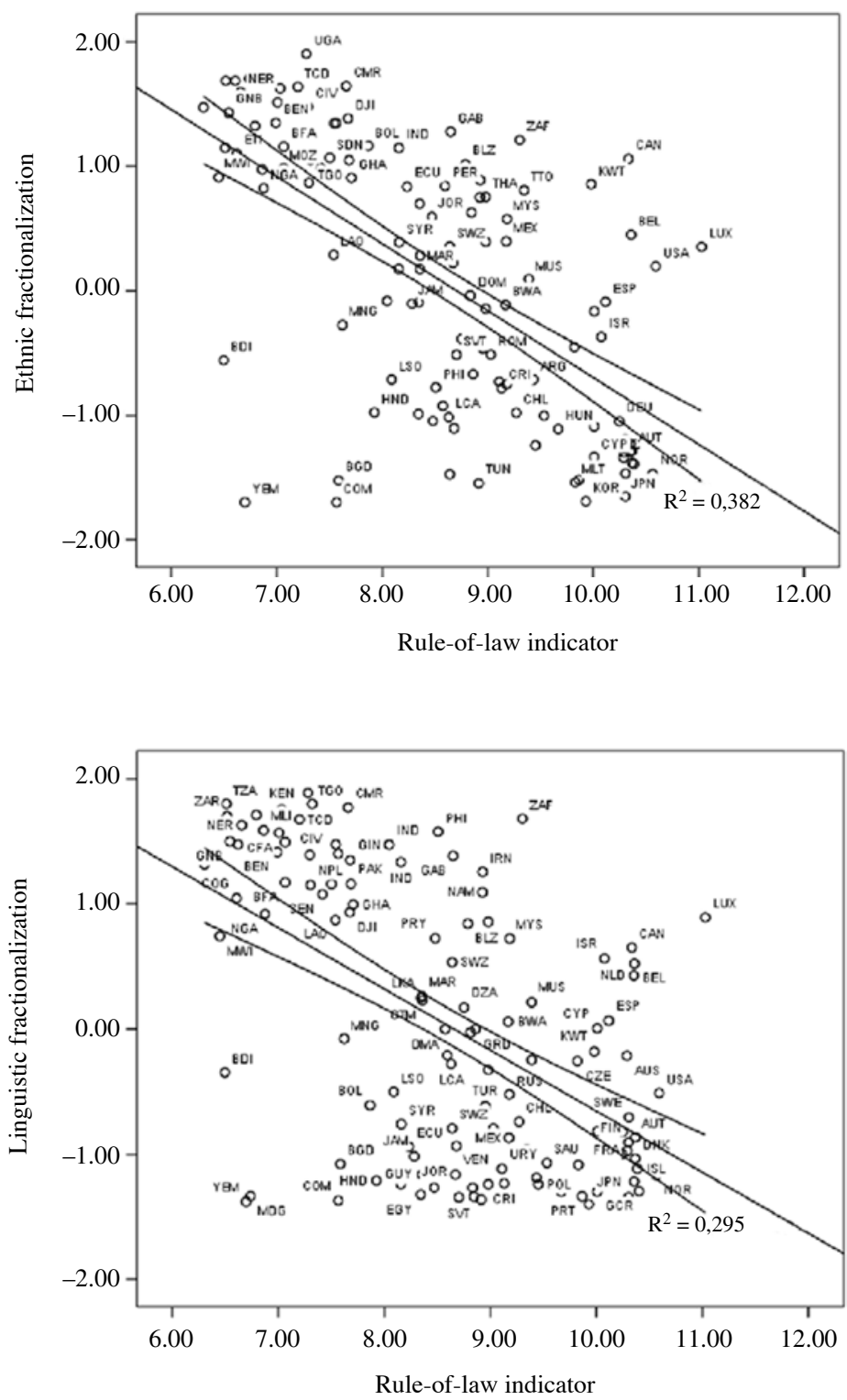

Source: Prepared by the author, on the basis of data from the World Bank (2006) and Alesina, Devleeschauwer and others (2003). 
an institutional response that is supposedly efficient in a developed country. Such impositions may actually revitalize informal institutions, turning them into strongholds for groups that feel threatened by the new institutional framework, thereby hindering processes of mobility and social change.

Given all of the above, an alternative explanation might be found to the one suggested by AJR and ES. It may

FIGURE 2

Ethnic and linguistic fractionalization and institutional quality

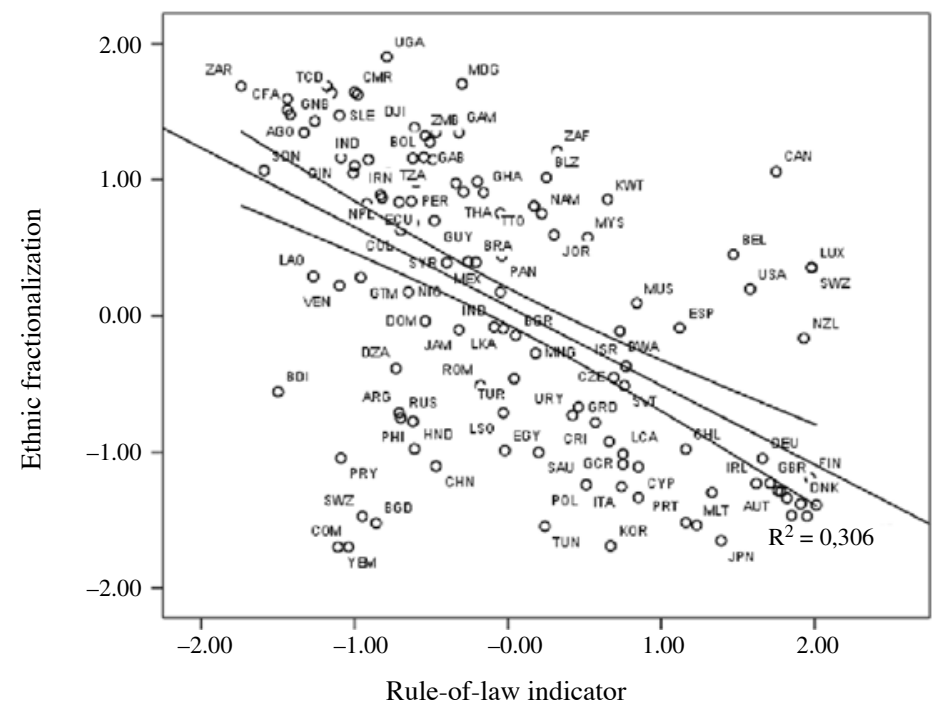

$\mathrm{R}^{2}=0,382$

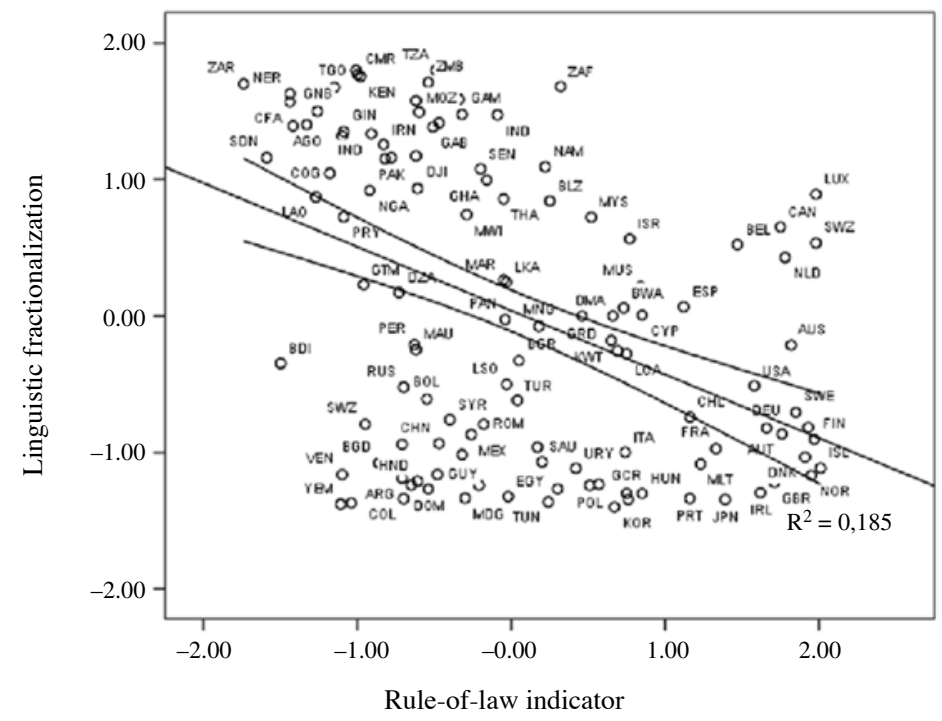

Source: Prepared by the author, on the basis of data from the World Bank (2006) and Kaufmann, Kraay and Mastruzzi (2005). 
be that, in countries where "land colonization" (settlement of virgin lands) was practised, formal institutions (partly imported from Europe) took hold, and, as a result, these countries were better prepared for mobility and social change, driven by changing market incentives. On the other hand, in countries where "people colonization" (with large indigenous groups) was practised, formal institutions overlapped (and sometimes clashed) with previously existing informal institutions, fostering social fractionalization and hindering the mobility and social change required by the market. According to this view, economic backwardness may have been caused less by colonial institutions themselves than by informal institutions' resistance to change, in a setting of social disarticulation brought about by colonization itself.

It is not easy to gather information on the fabric of informal institutions, and even less so when those institutions are part of the historical past. Social fractionalization (ethnic or linguistic) may be a good yardstick for measuring this phenomenon. The durability of ethnic and linguistic fractionalization can be used to create variables that express the prevalence of informal institutions. There is clearly a negative correlation between the degree of linguistic and ethnic fractionalization (see Alesina, Devleeschauwer and others, 2003) and the level of development measured in terms of 2004 per capita GDP, at purchasing power parity (figure 1).

As mentioned above, formal institutions are likely to be less effective in social contexts where informality is high (estimated in terms of social fractionalization). As shown in figure 2, although the linkage is not as clear, there is also a negative correlation between ethnic and linguistic fractionalization and institutional quality (measured by the rule-of-law indicator). ${ }^{2}$

\section{Do optimal institutions exist?}

The second problem with the interpretation offered by AJR and ES lies in the questionable assumption that it is possible to define what constitutes an optimal institutional framework without taking into account the social context of each country. The existence of multiple equilibria, the complementarity of institutions and the fact that the same institution might serve different purposes make it difficult to define a universal and optimal institutional response to any given problem. Moreover, even if there were consensus regarding an economic policy, there could

\footnotetext{
2 This indicator appears in a World Bank publication, and was developed by Kaufman, Kraay and Mastruzzi (2005).
}

be a wide range of institutional options for achieving that policy objective. This does not mean that any institutional response is valid, or that alternative options should not be considered, but rather that there are many possible responses - all of them equally acceptable - in a given context. This underscores the importance of taking local conditions into account when determining whether or not an institution is appropriate (Islam and Montenegro, 2002).

The relative specificity of institutions explains the relative effectiveness of so-called transitional institutions (Quian, 2003): mechanisms designed to adjust the existing institutional framework to changes in circumstances. These institutions are not designed to meet the rigid standards of supposedly optimal institutions, but rather allow for the correction of inefficiencies through a dynamic, highly specific process. From an abstract perspective, these institutions could probably be considered inefficient. They make transition possible, however, by adjusting to local conditions and fostering changes that are consistent with a country's development objectives. In this regard, the principle of "remediability" of institutional change cited by Williamson (1985) is worth remembering: an institution should not be considered inefficient unless a better, socially viable alternative exists. In other words, the efficiency of an institution should not be judged in terms of a supposedly universal design, but rather in light of the best options that are socially feasible.

For example, no one would point to China as an example of a market economy where property rights are protected (the two aspects of an institutional framework most valued by AJR); China, however, has been growing at average rates of nearly seven percent of per capita GDP for more than ten years. What is happening? Is it a successful economy trapped inside an inefficient institutional framework? A more likely explanation is that the country is generating highly specific institutional responses, which might be considered inefficient by the standards of an ideal market economy, but are highly conducive to change in the specific context of Chinese society. In this regard, the country's institutions satisfy the criterion of adaptive efficiency mentioned above.

In short, while the formal institutions established in the Hispanic New World may have been inefficient, one cannot assume that this was because they fell short of an optimal universal model; any conclusion regarding inefficiency should be based on the study of the specific social conditions of the societies involved. It does not seem unreasonable, therefore, to take a closer look at history, to try to determine the appropriateness of institutions and their inertia over time. 


\section{V}

\section{Empirical evidence of the importance of institutions}

The above approaches could be transposed, even if only tentatively, to an empirical model that could be used to begin a discussion of the arguments outlined above. In simple terms, three basic options have been suggested to explain the development levels of countries: (i) Gallup, Sachs and Mellinger (1998) and Sachs (2001) stress the importance of geography (particularly access to the sea and distance from the tropics); (ii) Acemoglu, Johnson and Robinson (2002) emphasize the importance of institutions, shaped by a country's colonization model; and (iii) Rodrik, Subramanian and Trebbi (2002) mention the potentially positive impact of trade, measured by the degree of trade liberalization. Nevertheless, despite their references to the instrumental variable developed by Frankel and Romer (1999), they did not find trade liberalization to be significant (and it figured with a negative sign).

Like Rodrik, Subramanian and Trebbi (2002), this article assumes that a country's level of development may be influenced by geography (measured in terms of distance from the tropics), institutional quality (measured by the rule-of-law indicator developed by Kaufmann, Kraay and Mastruzzi) and trade integration (measured by the degree of trade liberalization). The problem, however, is that the latter two variables (institutional quality and trade integration) are endogenous, as they may be influenced by a country's level of development. Suitable estimation tools must therefore be developed.

In this regard, and bearing in mind previous studies, emphasis will be placed on the role played by the size and accessibility of both the domestic and the proximate international markets. Market size determines the level of productive specialization and, sometimes, the use of the economies of scale involved in the industrialization process; while accessibility, measured by the inverse of distance, provides an estimate of the costs of trade. In order to convert this factor into a suitable estimation tool, the relative market size is calculated according to the populations of urban nuclei, since a country's commercial activities are concentrated in its cities. Population figures for 1890 are used, since that was when the arc of international income distribution began its course. In other words, as with gravitation models, the indicator of market attraction would be, $\sum \operatorname{Ln} \frac{P_{i} P_{j}}{L_{i j}}$

where $P$ represents the 1890 population, $i$ and $j$ the urban nuclei considered and $L$ the distance between the two.

This formula was applied to both domestic and international markets, although with different criteria. Specifically, in the case of domestic markets, all cities with a population of over 30,000 in 1870 were analysed, and the distance used was that between each urban nucleus and the capital of the country. Thus, the more urbanized a country is, and the shorter the distances between its urban nuclei, the larger the actual size of its domestic market will be. The size of international markets was measured using only the populations of the capitals of countries located within a maximum radius of 3,000 kilometres, which is a reasonable way to define a relatively proximate regional market.

The trade integration variable is determined by three factors: firstly, in negative terms, it is determined by the size of the domestic market, since the existence of a large domestic market reduces the need for international trade. Secondly - also in negative terms - it is determined by a country's size, measured by the population logarithm, which affects the measurement of openness. Finally, in positive terms, it is determined by the size of the proximate international market, which facilitates trade and improves the potential for international insertion.

The quality of institutions is determined by several factors. First of all, in a negative sense, it is determined by the level of fractionalization of a society, which reinforces the tendency of agents to resort to informal institutions, diminishing the effectiveness (and sometimes the credibility) of the formal institutional system. Social fractionalization can be expressed through two alternative variables, both of which produce similar results: linguistic fractionalization and ethnic fractionalization (both are discussed by Alesina, Devleeshauwer and others, 2003). Both variables express the probability of having two randomly selected individuals from the same country speaking different languages or having different ethnic origins. Secondly, institutional quality can also be influenced by a country's location, measured as its 
distance from the tropics. Environmental circumstances in the tropics adversely affect people's health and soil productivity, hindering social networking and institutional quality. Thirdly, population size may have a negative effect on the quality of institutions since, all other things being equal, it is easier to develop effective and credible institutions in smaller countries. Finally, the size of the domestic market may have a positive effect on institutional quality, since it is related, to some extent, to a country's level of urbanization.

The results of the estimation, which was performed using the ordinary least squares method in two stages (instrumental variables), suggest that development levels

TABLE 1

Factors determining development ${ }^{a}$

\begin{tabular}{|c|c|c|c|}
\hline \multirow[b]{2}{*}{$\mathrm{N}^{\mathrm{o}}$ of observations: 125} & \multicolumn{3}{|c|}{ Logarithm of per capita GDP to purchasing power parity, 2004} \\
\hline & \multicolumn{3}{|c|}{ Two stages (instrumental variables) } \\
\hline Institutions (rule of law) & $\begin{array}{c}0.975 \\
(6.829)\end{array}$ & & $\begin{array}{c}0.995 \\
(6.718)\end{array}$ \\
\hline Trade (trade liberalization) & $\begin{array}{l}-0.119 \\
(-0.614)\end{array}$ & & $\begin{array}{l}-0.197 \\
(-1.035)\end{array}$ \\
\hline Geography (distance from the tropics) & $\begin{array}{c}0.009 \\
(1.627)\end{array}$ & & $\begin{array}{l}0.008 \\
(1.493)\end{array}$ \\
\hline \multirow[t]{3}{*}{$\begin{array}{l}\mathrm{R}^{2} \\
\mathrm{R}^{2} \text { adjusted }\end{array}$} & $\begin{array}{l}0.668 \\
0.660\end{array}$ & & $\begin{array}{l}0.679 \\
0.671\end{array}$ \\
\hline & \multicolumn{3}{|c|}{ First stage for endogenous variables } \\
\hline & Rule of law & Rule of law & $\begin{array}{c}\text { Trade } \\
\text { liberalization }\end{array}$ \\
\hline Linguistic fractionalization & $\begin{array}{l}-0.183 \\
(-2.536)\end{array}$ & & \\
\hline Ethnic fractionalization & & $\begin{array}{c}-0.265 \\
(-3.151)\end{array}$ & \\
\hline Population & $\begin{array}{l}-0.173 \\
(-4.033)\end{array}$ & $\begin{array}{l}-0.173 \\
(-4.033)\end{array}$ & $\begin{array}{l}-0.143 \\
(-6.522)\end{array}$ \\
\hline Size of domestic market & $\begin{array}{r}0.225 \\
(3.390)\end{array}$ & $\begin{array}{c}0.215 \\
(3.279)\end{array}$ & $\begin{array}{l}-0.058 \\
(-1.762)\end{array}$ \\
\hline Size of regional market & & & $\begin{array}{c}0.085 \\
(2.630)\end{array}$ \\
\hline Geography & $\begin{array}{c}0.023 \\
(5.485)\end{array}$ & $\begin{array}{c}0.019 \\
(4.036)\end{array}$ & \\
\hline $\mathrm{R}^{2}$ & 0.429 & 0.445 & 0.404 \\
\hline $\mathrm{R}^{2}$ adjusted & 0.410 & 0.426 & 0.389 \\
\hline
\end{tabular}

Source: Prepared by the author.

a The variable for level of development is the per capita GDP for 2004 at purchasing power parity (World Bank); the variable for institutional quality (rule of law) is the rule-of-law indicator included in the governance indicators listed by Kaufmann, Kraay and Mastruzzi (2005); trade integration is expressed by the coefficient of liberalization (exports plus imports over GDP); the geographic variable is measured in absolute terms as latitude divided by 90; ethnic and linguistic fractionalization are taken from Alesina, Devleeschauwer and others (2003). Population figures are for 2004 (World Bank); size of domestic markets is based on all cities in a country that possessed 30,000 inhabitants in 1890 , and distance from the capital is based on the following formula:

$\sum_{i=1}^{n} \operatorname{Ln}\left[\left(p_{i}^{*} p_{i}\right) / d\right]$, where $p_{c}$ is the population of the capital in $1890, p_{i}$ is the population of cities with more than 30,000 inhabitants in 1900 and $d$ is the distance between the capital and each city; size of regional markets is estimated by applying the same formula to the population of the capitals of all countries located within a $3,000 \mathrm{~km}$ radius and the distance between them. 
can be explained, basically, by the institutional variable (table 1), thus supporting both Rodrik, Subramanian and Trebbi (2002) and the suggestions of AJR and ES. As noted in that study, the trade integration variable is not significant, and has a negative sign. The geographic variable operates with the right sign, and is almost significant. Nevertheless, geographic conditions also have a considerable impact on the quality of institutions, as was assumed in the model. Attention should also be paid to the explanatory capacity of variables constructed to measure the attraction potential of domestic and regional markets, which affect both economic openness and institutional quality.

The estimation results show that geography and institutions influence a country's development potential. However, the quality of institutions is not necessarily determined by a country's colonization model, but rather by the social fractionalization underlying its institutions. Where social fractionalization is high, institutions are of poorer quality, largely because there may still be a fractionalized network of informal institutions. At the same time, the existence of a network of proximate urban nuclei on which to establish a market determines both a country's potential for international insertion and the quality of its institutions. The latter is also influenced by the network of cities a country possesses; in addition to determining the size of the local market, such networks provide a basic idea of the level of urbanization. As for international insertion, what matters the most is that the country be located within a large and accessible regional environment.

Beyond the hypotheses supported by this empirical exercise, there is still the question of how individual countries have used the opportunities provided by each of the factors explained above. Why, for example, did Australia overcome the limited availability of regional markets, while Morocco failed to take advantage of that relative advantage? Or why did Canada overcome its relatively high linguistic fractionalization, while Madagascar failed to benefit from its greater homogeneity? These are questions that challenge the findings of historical research, and call for a study of the specific issues involved in each case.

\section{VI}

\section{Inequality, institutions and the bath water}

\section{Inequality and institutions}

In the preceding pages, an effort has been made to explain some of the limitations of the institutional hypothesis, as presented by its most qualified proponents. Its main limitation is its fruitless attempt to find a single, universal cause for underdevelopment. No development strategy can be applied everywhere, nor is there a single diagnosis of the factors that cause economic backwardness. This is true even for specific regions.

In the case of Latin America, for example, economic backwardness was probably caused by a variety of different factors, including geographic conditions (problems with transportation and communication between and within countries), historical chance (postponing industrialization even as the transportation revolution was under way), institutional responses (particularly the dislocation of formal and informal institutions) and economic policy choices (Haber, 2000). To these factors must be added the impact over time of the momentum that seems to be associated with rising productivity. It is hard to imagine that all of these factors could be reduced to a single cause.

The shortcomings found in the works of AJR and ES should not lead the reader to reject some of their hypotheses, which are highly suggestive. In other words, the baby should not be thrown out with the bath water.

Specifically, it seems plausible that inequality (in a broad sense, not just in terms of income) may determine the quality of collective action, and thus affect the efficiency and credibility of institutions; it is also reasonable to assume that these two issues efficiency and credibility - influence economic results, as well as the willingness of a country to embark upon social change. Thus, there is no need to accept all the arguments made by ES to assume that "greater equality or homogeneity among the population led, over time, to more democratic political institutions, more investment in public goods and infrastructures, and to institutions that offered relatively broad access to property rights and economic opportunities." (Engerman and Sokoloff, 
2006, p. 41). Nevertheless, it is important to (i) study in greater depth how the suggested relationship between inequality, institutions and growth operates; and (ii) consider the process of institutional change from a broader and more complex historical perspective.

The second issue is beyond the scope of this article. Nonetheless, it is important to note that no broad and convincing theory of institutional change has yet been developed (Lin and Nugent, 1995). The idea that the process of change follows a self-selective dynamic (as suggested by evolutionists), and that the most efficient institutions survive spontaneously, does not appear to be grounded in reality; neither does the assumption that institutional change arises solely from conflicts between competing interests, or from the pursuit of income on the part of individual or group agents in the complex political market (as suggested by the public choice school). The process of institutional change appears to be much more complex, involving not only material factors but also the cultural factors (worldviews) that are prevalent in a given society (Chang and Evans, 2000). That is why it is difficult to transplant existing institutional models or generate institutional realities ex novo in a given country. Historians may therefore play a key role in furthering the understanding of institutional change.

Further progress is possible, however, in the analysis of the relationship between inequality and institutional quality. In principle, an institution may be defined as an intertemporal contract, the effectiveness of which depends on two factors: (i) its social efficiency and (ii) its credibility. Efficiency is understood as the capacity of an institutional framework to reduce transaction costs and generate behaviour that is compatible with efficiency incentives - i.e., that allows for equilibrium in the interplay of institutions, in such a way that, from a dynamic perspective, everyone can benefit (or, at least, winners can compensate losers). Credibility is understood as the capacity of the institutional framework to influence the behaviour of agents - that is, to define valid intertemporal contracts. Both criteria are necessary, inasmuch as there is no point in having a supposedly efficient institution if it does not shape social conduct. At the same time, there is no guarantee that having legitimate institutions will necessarily lead to socially optimal responses.

The relationship between inequality and collective action may be considered in the light of three arguments that are not necessarily incompatible.

\section{(a) Inequality and collective action}

One of the basic reasons for building institutions is to provide public goods (of different types) for society. Many of these public goods require cooperative contributions from different agents. The theory of collective action suggests two hypotheses that link, in a negative sense, the levels of provision of a public good with the levels of equality of the group concerned. Firstly, in the case of impure public goods, Olson (1965) argues that large contributors are "exploited" by small ones: the former tend to assume the costs of provision, even when small contributors do not cooperate, because they receive greater net benefits from the public good. Secondly, in the case of pure public goods (in the absence of corner solutions), Cornes and Sandler (1996) have shown that the principle of neutrality prevails: provision is independent from the distribution of effort among contributors. In both cases, modelling occurs under highly restrictive assumptions, using a static two-player model.

A somewhat more complex proposition might be suggested: Baland and Platteau (2007) and Bardhan (2005) explore the consequences of inequality in a game that is extended over time. Bardhan and Singh (2004) discuss the possibilities of a multi-player model that allows for the formation of coalitions. The results of these proposals differ from those mentioned above, and suggest the existence of a direct relationship between equality and efficiency in providing public goods.

Bardhan (2005), in particular, discusses the existence of inequality in a non-transferable good (private capital, for example), and accepts increases in efficiency brought about by technological advances in the production of inputs that are complementary to capital. Although incentives for cooperation are greater among the wealthier members of the community (all else being equal), the result may vary according to the coalition structures resulting from existing levels of inequality. Among their main findings, Bardhan and Singh (2004) point out that a reduction of inequality can increase the willingness to cooperate of those whose relative position improves (box 1). In other words, under conditions more similar to social dynamics, reducing inequality improves the willingness of agents to cooperate. This position has been the subject of empirical studies by Bardhan and DaytonJohnson (2007) in water management communities in Mexico and south India, and by Cárdenas (2007) in the case of Colombia.

\section{(b) Inequality and institutional instability}

The previous section dealt with the correlation between inequality and incentives for cooperative action. 
Box 1

SIMPLE MODEL OF THE IMPACT OF INCREASED INEQUALITY

ON THE PROVISION OF PUBLIC GOODS

A decentralized assignment model is posited in which each player plays independently. Total production of a collective good is $X=\sum x_{i}$. Each individual action is added through the following linear function: $z_{i}=b x_{i}+c X$. In the case of positive externalities and pure public goods, $c>0$ and $b=0$; if the public good is impure, $c>0$ and $b>0$. In the case of negative externalities and a common good, $c<0$ and $b>0$; in the case of a private good, $c=0$ and $b>0$.

In a Nash equilibrium, each player chooses an optimum action given the action chosen by the others. In other words, each player resolves as follows:

$$
\max \pi^{i}=f\left(w_{i}, z_{i}\right)-x_{i}
$$

With the function $g\left(w_{i}\right)>0$ as the value of $z_{i}$ that resolves the first-order conditions of the previous function, stated as an equality

$$
f_{2}\left(w_{i}, g\left(w_{i}\right)\right)(b+c)=1
$$

$g(w)$ represents the level of the collective input $z$ that $i$ would choose given his wealth $w$. Individual players can only affect the collective good through their respective contributions. If $x$ is the optimum choice of a player, as

$\hat{x}_{i}=\frac{g\left(w_{i}\right)-c X}{b}$

Decreasing yields in the collective good are now posited. $X=\frac{\sum g\left(w_{i}\right)}{b+m c}$ can be derived from the previous equation,

where $m$ is the number of agents in the equilibrium. Thus, $X$ is the sum of $m$ concave functions and, consequently, $X$ itself is concave. In this case, the contribution is maximized when all the agents have the same amount of the private input.

This is now applied to the case of two agents, where the wealth of one (1) is $w+\varepsilon$ and that of the other (2) is $w-\varepsilon$, with $\varepsilon>0$. Let us consider the response functions of each player

$$
\begin{aligned}
& x_{1}=\frac{1}{b+c}\left[g(w+\varepsilon)-c x_{2}\right] \\
& x_{2}=\frac{1}{b+c}\left[g(w-\varepsilon)-c x_{1}\right]
\end{aligned}
$$

In order to see a change in distribution, let us assume that distribution increases from $\varepsilon$ to $\varepsilon^{\prime}$, which would increase $x_{1}$ and reduce $x_{2}$. In the case of positive externalities, the results are shown in the figure. The displacement of $R_{2}$ is greater than that of $R_{1}$

Given the concavity assumption, the difference between $g(w-\varepsilon)$ and $g\left(w-\varepsilon^{\prime}\right)$ is greater than the difference between $g(w+\varepsilon)$ and $g\left(w+\varepsilon^{\prime}\right)$. The new point of equilibrium $(B)$ is below and to the left of the isocontribution straight line. In other words, as inequality increases, there is an aggregate loss (the reduction of the contribution by 2 is greater than the increase in the contribution by 1). This result follows from the assumptions applied above.

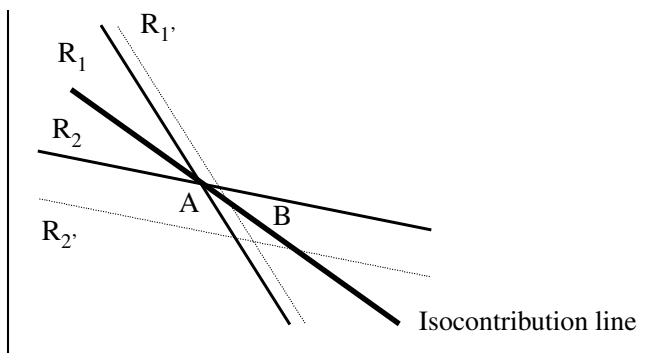

Source: Based on Bardhan, Ghatak and Karaivanov (2007). 
The same problem could be viewed from a political perspective. In principle, there are three basic mechanisms whereby an institution becomes self-replicating: tradition (one does what has always been done); coercion (one must do something to avoid a penalty); and shared willingness (one does what has been agreed because it is a reasonable solution to a coordination problem). While all these mechanisms may be effective, the last one is the least likely to elicit criticism, and the most likely to ensure the stability of the institutional framework.

Nevertheless, in order for this shared willingness to be possible, the institutional equilibrium must meet the expectations of the agents involved. They will not readily support an institutional framework that systematically produces a highly unequal distribution of the benefits arising from collective action (Easterly,
Ritzan and Woolcock, 2005). In such cases, the institutional equilibrium will be called into question, and attempts will be made to alter the rules of the game. This explains why there is a close association between marked inequality and institutional instability (Alesina and Perotti, 1996).

This proposition can be stated in more formal terms if institutions are understood in terms of a game extended over time - that is, a game based on repeated interaction between agents. The distribution of benefits arising from collective action is crucial to ensuring that the players are inclined to cooperate, even if the static structure of the game is that of the prisoner's dilemma (box 2 and Alonso, 2006). This suggests that the credibility of institutions depends, to a large extent, on their ability to generate inclusive responses.

\section{Box 2}

POSSIBILITIES FOR COOPERATION IN DYNAMIC GAMES

From a dynamic perspective, the conclusions arising from the prisoner's dilemma may be substantially altered by increasing opportunities for cooperation and efficiency. To illustrate this point, the structure of the prisoner's dilemma can be applied to a case in which successive moves are allowed. Each agent has three possible strategies: the two already known - defection and cooperation - and a third - reciprocity - in which the response of one player is met in the same fashion by the other player. Since decisions have consequences over time, the existence of a discount rate must be considered, such that the present value of a given net benefit $b$ will extend over an infinite number of years: $b /(1-r)$. Let us assume the supply of public goods costs is 10 , and the benefits obtained from those goods are eight for each agent. The following scenarios are possible:

If both players choose reciprocity on the bases of cooperation, in the first round each player will obtain 6/(1-r) (box 1). The result is the same when one player decides to cooperate and the other acts reciprocally, or when both cooperate (boxes 2,4 and 5). On the other hand, when one player chooses reciprocity and the other chooses defection, the first player will obtain a result of -2 in the first round and zero in the rest, while the second player will obtain 8 and 0 , respectively (boxes 3 and 7). When one player systematically decides to cooperate and the other to defect, the first player will obtain $-2 /(1-r)$ and the second will obtain 8/(1-r) (boxes 6 and 8). Finally, if both decide not to cooperate in all rounds, they will both obtain 0 (box 9).

The two players do not have a predominant strategy, but rather two Nash equilibria. One is the usual result of the prisoner's dilemma (box 9), but the other one is an efficient solution (box 1). In other words, the simple act of introducing a dynamic perspective and allowing for the existence of a strategy of reciprocity is enough to create the possibility of an efficient response

Prisoner's dilemma with infinite games

\begin{tabular}{lccc}
\hline & \multicolumn{2}{c}{ Reciprocity } & Cooperation \\
\hline Reciprocity & $6 /(1-r) ; 6 /(1-r)^{(1)}$ & $6 /(1-r) ; 6 /(1-r)^{(2)}$ & $-2,0 ; 8,0$ \\
Cooperation & $(4)$ & $6 /(1-r) ; 6 /(1-r)^{(5)}$ & $-2 /(1-r) ; 8 /(1-r)^{(6)}$ \\
Defection & $6 /(1-r) ; 6 /(1-r))^{(8)}$ & & $(9)$ \\
& $-2,0 ; 8,0^{(7)}$ & $-2 /(1-r) ; 8 /(1-r)^{(8)}$ & $0 ; 0$ \\
\hline
\end{tabular}

Source: Prepared by the author. 


\section{c) Inequality and informal institutions}

Finally, social inequality can drive certain segments of society to resort to informal institutions as defence mechanisms and for collective protection. These institutions are not always dysfunctional, but they are usually less coordinated with the market and more resistant to change, as noted above. Hence, this option seems to hamper the development and efficacy of formal institutions, as well as the flexibility and willingness to change of the existing institutional framework. In this case, inequality operates through its impact on the development of informality. This is not a forced assumption, given that the available data (still of poor quality) reveal a direct correlation between levels of inequality of countries and the relative weight of their informal sectors (as shown by Perry, Maloney and others, 2007).

\section{Inequality and social mobility}

Although inequality has been mentioned without going into detail, the arguments set forth - particularly in the last two cases - become more relevant when discussing horizontal inequality - that is, inequality between groups of people- in an environment of limited social mobility. Willingness to cooperate is more seriously jeopardized when inequality generates mechanisms of solidarity between affected groups. This is the case when horizontal inequality is high and social mobility is low. Likewise, the tendency to resort to informal institutions increases when social fractionalization is high, which occurs in situations of horizontal inequality and low social mobility.

\section{VII}

\section{Final remarks}

The arguments set forth above lead to certain conclusions that may be helpful when considering a development agenda for Latin America. In short:

1. The region is characterized by marked social inequality. It is debatable, however, whether this feature can be traced back five hundred years to the colonial period. Historical studies seem to suggest that inequality (along with economic backwardness) is a much more recent phenomenon that arose in the late nineteenth century. Factors such as Latin America's postcolonial model of international
Social mobility plays a significant role in this regard. To put it the other way around, even in a context of inequality, social mobility helps mitigate the tendency to question the existing institutional framework: the success of some underprivileged individuals encourages the rest (this is the "tunnel effect" suggested by Hirschman, 1981). The absence of personal success is viewed as a consequence of one's own inability (others have succeeded), rather than as a limitation of the existing institutional order. The absence of social mobility in an environment of marked inequality feeds the tendency to question the existing institutional framework, increasing the level of instability and conflict within a society.

The analyses above are relevant when judging the case of Latin America, given that the region is characterized not only by a high level of vertical inequality, as shown by the Gini inequality index, but also by marked horizontal inequality and very low social mobility (although this characteristic is not universal, and has been less researched than others). Horizontal inequality is revealed by an analysis of vectors of poverty, which define the asymmetrical probabilities of being poor as a function of the population's living in a rural or urban area or of its ethnic origin (indigenous, mestizo or white). Limited social mobility is reflected by the fact that the poverty of one generation (parents) is highly predictive of the poverty of the next (children). Thus, it is not surprising that institutional quality is a serious problem in Latin America. Overcoming it will entail not only improving the technical aspects of the institutional response, but also taking action on the social legitimacy of institutions themselves, which is closely tied to the distribution patterns with which they are associated. insertion (based on the exploitation of natural resources), the massive influx of immigrants that preceded the First World War and the existence of institutions that were ill-suited to social change may have contributed to such a result.

2. This is not to say that institutions do not play a significant role in determining the dynamics of a country's long-term growth. In fact, empirical analysis seems to support the proposition that institutional quality is important in the long run. 
Nevertheless, this factor must be considered along with others, such as market access.

3. Not enough is known, however, about the keys to institutional change, and there are well-founded doubts regarding whether an optimal institutional framework is even possible. On the contrary, there are probably sub-optimal solutions that can be effective under the specific conditions of a given economy. Consequently, local conditions must be taken into account when assessing the quality of institutions.

4. The institutional framework is made up of formal and informal institutions. Nevertheless, given their greater transparency, formal institutions are better suited to change, and allow for greater social mobility. In traditional or highly fractionalized societies, underprivileged sectors tend to resort to informal institutions. Such informality can hinder social change.

5. The quality of institutions depends on their efficiency and their credibility. Both factors can be affected by the existing levels of inequality: efficiency, because the strategic game can lead to results that are not compatible with the framework of incentives; credibility, because the unequal distribution of the fruits of collective action can limit the willingness to cooperate of the social agents that have been harmed.

6. A closer look at the correlations mentioned above shows that inequality can influence the quality of institutions in at least three different ways: (i) it may limit the provision of public goods; (ii) it weakens confidence in the intertemporal contracts that institutions promote; and (iii) it encourages recourse to informal institutions. All of these factors can affect an economy's potential for growth.

7. Finally, vertical inequality is not the only relevant issue; horizontal inequality and the lack of social mobility are also extremely important. These last two factors are key to understanding the relationship between distribution patterns and institutional quality.

(Original: Spanish)
Acemoglu, D. and S. Johnson (2003): Unbundling Institutions, NBER Working Paper, No. 9934, Cambridge, Massachusetts, National Bureau of Economic Research.

Acemoglu, D., S. Johnson and J.A. Robinson (2001): The colonial origins of comparative development: an empirical investigation, American Economic Review, vol. 91, No. 5, Nashville, Tennessee, American Economic Association, December.

(2002): Reversal of fortunes: geography and institutions in the making of the modern world income distribution, Quarterly Journal of Economics, vol. 117, No. 4, Cambridge, Massachusetts, The MIT Press, November.

(2006): Understanding prosperity and poverty: geography, institutions, and the reversal of the fortune, Understanding Poverty, A. Banerjee, R. Bénabou and D. Mookherjee (eds.), New York, Oxford University Press.

Acemoglu, D. and J. Robinson (2000): Why did the West extend the franchise? Democracy, inequality, and growth in historical perspective, Quarterly Journal of Economics, Cambridge, Massachusetts, The MIT Press.

(2002): Economic Backwardness in Political Perspectives, NBER Working Paper, No. 8831, Cambridge, Massachusetts, National Bureau of Economic Research, March.

Alesina, A., A. Devleeschauwer and others (2003): Fractionalization, Journal of Economic Growth, vol. 8, No. 2, Amsterdam, Springer Netherlands.

Alesina, A. and R. Perotti (1996): Income distribution, political instability and investment, European Economic Review, vol. 40, No. 6, Amsterdam, Elsevier.

Alonso, J.A. (2006): International Public Goods for Economic Development, unpublished.

Baland, J.M. and J.PH. Platteau (2007): Collective action and the commons: the role of inequality, in J.M. Baland, P. Bardhan and S. Bowles (eds.), Inequality, Cooperation and Environmental Sustainability, Princeton, Princeton University Press.

Banerjee, A. and L. Iyes (2005): History, institutions and economic performance: the legacy of colonial land tenure system in
India, American Economic Review, vol. 95, No. 4, Nashville, Tennessee, American Economic Association.

Bardhan, P. (2005): Scarcity, Conflict, and Cooperation: Essays in the Political and Institutional Economics of Development, Cambridge, Cambridge University Press.

Bardhan, P. and J. Dayton-Johnson (2007): Inequality and the governance of water resources in Mexico and South India, in J.M. Baland, P. Bardhan and S. Bowles (eds.), Inequality, Cooperation and Environmental Sustainability, Princeton, Princeton University Press.

Bardhan, P. and N. Singh (2004): Inequality, coalitions, and collective action, unpublished.

Bardhan, P., M. Ghatak and A. Karainov (2007): Inequality and collective action, in J.M. Baland, P. Bardhan and S. Bowles (eds.), Inequality, Cooperation and Environmental Sustainability, Princeton, Princeton University Press.

Bértola Flores, L. (2005): A 50 años de la curva de Kuznets: crecimiento económico y distribución del ingreso en Uruguay y otras economías de nuevo asentamiento desde 1870, Investigaciones de historia económica, No. 3, Madrid, Asociación Española de Historia Económica.

Bourguignon, F. and Ch. Morrison (2002): The size distribution of income among world citizens, 1820-1990, American Economic Review, vol. 92, No. 4, Nashville, Tennessee, American Economic Association, September.

Bulmer-Thomas, V. (1994): The Economic History of Latin America since Independence, Cambridge, Cambridge University Press.

Cardenas, J.C. (2007): Wealth inequality and overexploitation of the commons: field experiments in Colombia, in J.M. Baland, P. Bardhan and S. Bowles, Inequality, Cooperation and Environmental Sustainability, Princeton, Princeton University Press.

Carmagnani, M. (2004): El otro Occidente. América Latina desde la invasión europea hasta la globalización, Mexico City, Fondo de Cultura Económica/Colegio de México.

Chang, H-J. and P. Evans (2000): The role of institutions in economic change, document prepared for "The Other Canon" Conference. 
Coatsworth, J.H. (2005): Structures, endowments, and institutions in the economic history of Latin America, Latin American Research Review, vol. 40, No. 3, Austin, Texas, University of Texas Press.

(2007): Inequality, Institutions, and Economic Growth in Latin America, unpublished.

Coatsworth, J.H. and G. Tortella (2002): Institutions and Long-Run Economic Performance in Mexico and Spain, 1800-2000, document prepared for the XIII Congress of the International Economic History Association.

Cornes, R. and T. Sandler (1996): The Theory of Externalities, Public Goods, and Club Goods, Cambridge, Cambridge University Press.

De Ferranti, D., G. Perry and others (2004): Inequality in Latin America: Breaking with History? Washington, D.C., World Bank.

Diamond, J. (1998): Guns, Germs and Steel: the Fates of Human Societies, New York, W.W. Norton.

(2005): Collapse, New York, Penguin Group.

Dobado, R. (2007): Herencia colonial y desarrollo económico en Iberoamérica, unpublished.

Easterly, W., J. Ritzan and M. Woolcock (2005), Social cohesion, institutions, and growth, Washington, D.C., Banco Mundial, unpublished.

Elliott, J.H. (2006): Imperios del mundo atlántico. España y Gran Bretaña en América (1492-1830), Madrid, Santillana Ediciones Generales.

Engerman, S.L. and K.L. Sokoloff (1997): Factor endowments: institutions and differential paths of growth among new world economies. A view from economic historians of the United States, in S. Haber, How Latin America Fell Behind: Essays on the Economic Histories of Brazil and Mexico, 1800-1914, Stanford, Stanford University Press.

(2002): Factor Endowments, Inequality, and Paths of Development Among the New World Economies, NBER Working Paper, No. 9259, Cambridge, Massachusetts, National Bureau of Economic Research.

(2005): Colonialism, Inequality, and Long-run Paths of Development, NBER Working Paper, No. 11057, Cambridge, Massachusetts, National Bureau of Economic Research,

(2006): Colonialism, inequality, and long-run paths of development, in A.V. Banerjee, R. Bénabou and D. Mookherjee (eds.), Understanding Poverty, Oxford, Oxford University Press.

Engerman, S.L., S.H. Haber and K.L. Sokoloff (2000): Inequality, institutions, and differential paths of growth among new world economies, in C. Menard (ed.), Institutions, Contracts, and Organization, Cheltenham, Edward Elgar.

Frankel, J.A. and D. Romer (1999): Does trade cause growth?, American Economic Review, vol. 89, No. 3, Nashville, Tennessee, American Economic Association, June.

Gallup, J.L., A. Gaviria and E. Lora (2003): América Latina: ¿condenada por su geografía?, Bogotá, D.C., Inter-American Development Bank/Alfaomega Colombiana.

Gallup, J.L., J. Sachs and A. Mellinger (1998): Geography and Economic Development, NBER Working Paper, No. 6849, Cambridge, Massachusetts, National Bureau of Economic Research.

Gelman, J. (2007): ¿Crisis postcolonial en las economías sudamericanas? Los casos del Río de la Plata y Perú, unpublished.

Greif, A. (1994): Cultural beliefs and the organization of society: a historical and theoretical reflection on collectivist and individualist societies, Journal of Political Economy, vol. 102, Chicago, The University of Chicago Press.

(2004): Institutions: Theory and History, unpublished.

Greif, A., P. Milgrom and B. Weingast (1994): Coordination, commitment and enforcement: the case of the merchant guild, Journal of Political Economy, vol. 102, Chicago, The University of Chicago Press.

Haber, S. (1997): How Latin America Fell Behind: Essays on the Economic Histories of Brazil and Mexico, 1800-1914, Stanford, Stanford University Press. (ed.) (2000): Political Institutions and Economic Growth in Latin America, Stanford, Hoover Institutions Press.

Hirschman, A.O. (1981): Essays in Trespassing, Cambridge, Cambridge University Press.

Islam, R. and C. Montenegro (2002): What Determines the Quality of Institutions?, Policy Research Working Paper Series, No. 2764, Washington, D.C., World Bank.

Kaufmann, D., A. Kraay and M. Mastruzzi (2005): Governance Matters IV: Governance Indicators for 1996-2004, Washington, D.C., World Bank.

Landes, D.S. (1998): The Wealth and Poverty of Nations: Why Some Are So Rich and Some So Poor, New York, W.W. Norton.

Lin, J.Y. and J.B. Nugent (1995): Institutions and economic development, in J. Behrman and T.N. Srinivasan (eds.), Handbook of Economic Development, vol. 3, Amsterdam, North-Holland.

Mann, Ch.C. (2006): 1491. Una nueva historia de las Américas antes de Colón, Bogotá, D.C., Taurus.

Miño, M. (1991): Obrajes y tejedores de Nueva España 1700-1810, Madrid, Instituto de Estudios Fiscales.

North, D.C. (1990): Institutions, Institutional Change and Economic Performance, New York, Cambridge University Press.

(1993): The New Institutional Economics and Development, Saint Louis, Washington University.

(2005): Understanding the Process of Economic Change, Princeton, Princeton University Press

Olson, M. (1965): The Logic of Collective Action. Public Goods and Theory of Groups, Cambridge, Cambridge University Press.

Perry, G., O. Arias and others (2006): Poverty Reduction and Growth: Virtuous and Vicious Circles, Washington, D.C., World Bank.

Perry, G., W. Maloney and others (2007): Informalidad: escape y exclusión, Washington, D.C., World Bank.

Prados de la Escosura, L. (2005): Growth Inequality and Poverty in Latin America: Historical Evidence, Controlled Conjectures, Working Papers in Economic History, No. 54104, Madrid, Universidad Carlos III.

Pritchett, L. (1997): Divergence, big time, Journal of Economic Perspectives, vol. 11 No. 3, Nashville, Tennessee, American Economic Association.

Przeworski, A. and C. Curvale (2005): Does politics explain the economic gap between the United States and Latin America?, New York, New York University, unpublished.

Quian, Y. (2003): How reform worked in China, in D. Rodrik (ed.), In Search of Prosperity. Analytic Narratives on Economic Growth, Princeton, Princeton University Press.

Rodrik, D., A. Subramanian and F. Trebbi (2002): Institutions Rule: The Primacy of Institutions Over Geography and Integration in Economic Development, IMF Working Paper, No. 02/189, Washington, D.C., International Monetary Fund.

Sachs, J. (2001): Tropical Underdevelopment, NBER Working Paper Series, No. 8119, Cambridge, Massachusetts, National Bureau of Economic Research.

Sokoloff, K. and S.L. Engerman (2000): Institutions, factor endowments, and paths of development in the new world, Journal of Economic Perspectives, vol. 14, No. 3, Nashville, Tennessee, American Economic Association.

Velasco, C., E. Flores and others (1988): Estado y minería en México, 1767-1910, Mexico City, Fondo de Cultura Económica.

Williamson, J. (1999): Real wages, inequality and globalization in Latin America before 1940, Revista de historia económica, vol. 17, Madrid, Fundación SEPI.

Williamson, O.E. (1985): Economic Institutions of Capitalism, New York, The Free Press.

World Bank (2005): World Development Report 2006: Equity and Development, Madrid, Mundi-Prensa Libros S.A. (2006): World Development Indicators, Washington, 